Домбровская А. Ю.', Никулин Е. P. ${ }^{2}$
Дискурсивное поле внешнеполитических установок в белорусском сегменте социальных медиа: технологический аспект

Московский педагогический государственный университет, ул. Малая Пироговская, д. 1, стр. 1, Москва, 119991, Россия; ${ }^{1}$ au.dombrovskaya@mpgu.su; ${ }^{2}$ egor.nikulin.98@bk.ru

Аннотация: Исследование посвящено анализу технологий формирования внешнеполитических установок граждан Республики Беларусь. В процессе исследования были изучены теории и концепции, объясняющие роль и место современных Интернет-коммуникаций в политической сфере общества, проанализированы подходы к пониманию “установки" и процесса ее конструирования. Кроме этого, исследованы теоретические аспекты социально-медийной коммуникации, которые стали основой для методологической базы. Осуществлен анализ информационных потоков методом когнитивного картирования в социально-медийной сфере с помощью адаптированных под наши задачи упомянутых выше теорий, разработана и заполнена матрица, которая затем проанализирована в программе SPSS Statistics, на основе чего были сделаны выводы о технологиях формирования внешнеполитических установок белорусов. Интернет-платформой как источником данных выбрана социальная сеть “ВКонтакте", так как именно она, согласно данным рейтинговых служб и исследований, является самой популярной и политизированной в белорусском Интернет-сегменте.

Ключевые слова: внешнеполитическая установка; информационный поток; дискурс; социальная сеть; внешнеполитическая ориентация, белорусский сегмент.

Для цитирования: Домбровская А.Ю., Никулин Е.Р. Дискурсивное поле внешнеполитических установок в белорусском сегменте социальных медиа: технологический аспект // Научный результат. Социальные и гуманитарные исследования. 2020. Т. 6. № 1. С. 74-89. DOI: 10.18413/2408-932X-2020-6-1-0-8

\title{
A. Yu. Dombrovskaya ${ }^{1}$, Discourse field of foreign policy agenda E. R. Nikulin ${ }^{2} \quad$ in the Belarusian segment of social media: technological aspect
}

Moscow State Pedagogical University, bld. 1, 1 Malaya Pirogovskaya St., Moscow, 119991, Russia; ${ }^{1}$ au.dombrovskaya@mpgu.su; ${ }^{2}$ egor.nikulin.98@bk.ru

Abstract. This work is devoted to the analysis of technologies for the formation of foreign policy agenda of citizens of the Republic of Belarus. In the course of the study, we investigated theories and concepts that explain the role and place of modern Internet communications in the political sphere of society, analyzed approaches to understanding the "agenda" and the process of its development. In addition, the theoretical aspects of social media communication have been investigated, which 
have become the basis for our methodological base. We conducted an analysis of information flows by the method of cognitive mapping in the SM sphere using the above-mentioned theories adapted to our tasks, developed and filled out a matrix, which was subsequently analyzed in the SPSS Statistics program, on the basis of which technologies for the formation of foreign policy agenda of Belarusians were studied. The social network "VKontakte" served as the Internet platform for this work, since, according to rating services and research it is the most popular and politicized in the Belarusian Internet segment.

Keywords: foreign policy agenda; information flow; discourse; social network; foreign policy orientation; Belarusian segment

For citation: Dombrovskaya A. Yu. and Nikulin E. R., (2020), "Discourse field of foreign policy agenda in the Belarusian segment of social media: technological aspect", Research Result. Social Studies and Humanities, $6(1)$, 74-89, DOI: $10.18413 / 2408-932 X-2020-6-1-0-8$

Проблемным полем, актуализирующим данное исследование, служит факт того, что на сегодняшний день в медийном пространстве Республики Беларусь (далее РБ) идет активное обсуждение внешнеполитической ориентации страны в условиях уплотнения информационных потоков и активизации дискурса о цивилизационном векторе страны. РБ - одно из немногих постсоветских государств, которое официально имеет союзнические отношения с Российской Федерацией (далее РФ) и декларирует своей приоритетной задачей углубление и ускорение интеграционных процессов с РФ ${ }^{1}$. В связи с этим следует заметить, что не только сегодня, но и в ближайшей перспективе (особенно в период транзита власти после ухода с политической сцены А.Г. Лукашенко) внешнеполитическая проблематика белорусского государства станет ключевой темой политического дискурса в стране. Подчеркнем, что контент дискурса будет носить ярко выраженный биполярный характер: с одной стороны, основная тематика информационных потоков будет пророссийской, а с другой - прозападной. Данная дихотомичность объясняется кон-

\footnotetext{
1 Договор о создании Союзного государства. Информационный портал Союзного государства [Электронный pecypc] URL: http://www.soyuz.by/about/docs/dogovor5/ (дата обращения: 23.05.2019)
}

цепцией "Столкновения мировых цивилизаций” С. Хантингтона (Huntington, 1996), где современная РБ является границей Православной (Российской) и Западной цивилизаций.

Поскольку традиционные СМИ в РБ подвергаются государственному контролю и цензурированию ${ }^{2}$, то основные информационные потоки, касающиеся различных проблем белорусского общества, в том числе и сферы наших исследовательских интересов, целесообразно искать в онлайн-сетевой среде. Подчеркнем, что особое место в данном процессе занимает манипулятивная составляющая, с помощью которой политические акторы соседнего государства стремятся реализовать свои интересы в сфере общественного мнения. В связи с этим особый интерес в данном исследовании представляют доминирующие технологии, используемые политическими акторами в онлайн-сетевом пространстве в процессе формирования внешнеполитических установок белорусских пользователей.

Для изучения технологического аспекта формирования внешнеполитических предпочтений граждан РБ следует осуще-

\footnotetext{
${ }^{2}$ Беларусь. Ограничение политических и гражданских прав граждан после президентских выборов 2010 г. [Электронный ресурс] URL: https://www.fidh.org/IMG/pdf/rapport_Belarus_RUS web.pdf (дата обращения:23.09.2019)
} 
ствить комплексный структурный анализ процесса конструирования внешнеполитической ориентации Интернет-пользователей в онлайн-сетевом пространстве РБ.

Теоретическую основу статьи логично разделить на три группы. Первая из них оправдывает реализацию исследования в рамках онлайн-пространства. Вторая способствует разработке понятийного аппарата работы. Третья (прикладная) является основанием составленного нами инструментария (матрицы).

Строить теоретическую базу данной работы, с нашей точки зрения, следует начать с работ М. Кастельса. Именно его труды актуализируют исследования социально-медийного пространства в аспекте усиления влияния контента социальных сетей на установки, в том числе и внешнеполитические. «Именно сети составляют новую социальную морфологию наших обществ, а распространение “сетевой” логики в значительной мере сказывается на ходе и результате процессов, связанных с производством, повседневной жизнью, культурой и властью» - отмечает М. Кастельс (Castells, 2009).

Также для нас актуально рассмотреть концепцию «эффекта эха» в социальных сетях, разработанную С. Грином (Грин, 2012). Данное «эхо» долго транслирует с помощью мемов те или иные посылы политических акторов или явлений, которые могут быть наполнены внешнеполитическим содержанием. Кроме того, они, как главная причина и проявление «эха», консолидируют людей вокруг общих мемов, что в рамках политического дискурса касательно внешнеполитической ориентации Интернет-пользователей интересно для исследования.

Вышеперечисленные работы показывают актуальность изучения сетевых процессов на наличие в них технологий формирования различных установок, в том числе и внешнеполитических.

Первостепенной задачей реализации данного исследования является определение смысловой составляющей термина «внешнеполитическая установка». Определений в научной литературе достаточно много, и зачастую они расходятся в основополагающих характеристиках. С нашей точки зрения, наиболее приемлемым для нашего исследования будет адаптировать определения социальной установки, данные П.Н. Шихиревым (Шихирев, 2000) и С.К. Рощиным (Рощин, 1980), под тематику нашей работы. Согласно их трудам, социальная установка - это психологическая предрасположенность, готовность личности действовать определенным образом по отношению к определенному объекту. Если рассматривать данное определение в контексте нашей работы, то внешнеполитическую установку целесообразно представить в качестве психологической предрасположенности, имеющей в своей основе искусственно созданную манипулятивную составляющую, а также характеризующейся устойчивым отношением к тому или иному внешнеполитическому объекту в прошлом, настоящем и будущем.

Процесс конструирования установки, с нашей точки зрения, наиболее широко и доступно охарактеризовал советский психолог Д.Н. Узнадзе в своей «Теории установки» (Узнадзе, 1949). По мнению Д.Н. Узнадзе, для формирования установки необходимы потребность и ситуация, при которой индивид в состоянии ее удовлетворить. Автор отмечал, что в случае единичного повторения установка имеет диффузное состояние. В случае неоднократного повторения условий формирования той или иной установки, она становится фиксированной. Следовательно, создавая определенные потребности в обществе и «верные» ситуации для их удовлетворения, можно формировать, в том числе и внешнеполитические, установки общества.

Таким образом, нами определено понятие внешнеполитической установки и процесс ее (искусственного) формирования.

Однако в данной работе мы считаем необходимым опираться на труды еще одного пула исследователей, изучающих 
контент информационных потоков политической тематики, для трансформирования их описательных критериев в параметры матрицы для проводимого нами анализа.

Как отмечалось выше, характер формирования внешнеполитических установок имеет манипулятивную основу, поэтому целесообразно проанализировать технологии Интернет-манипуляций. Например, Л.Х. Ибрагимов (Ибрагимов, 2015) анализирует классификацию методов манипуляции общественным сознанием С.В. Володенкова и апробирует их результативность в Интернет-пространстве. С нашей точки зрения, особое внимание в данной работе следует уделить таким технологиям манипулятивного воздействия, как: метод повторения, метод наклеивания ярлыков, метод «общего вагона», метод утечки секретной информации, метод «спирали молчания», метод универсальности, метод объективного подхода и метод семантического манипулирования. Считаем целесообразным более подробно проанализировать каждый из представленных методов манипуляции. Метод повторения и метод наклеивания ярлыков - простые и эффективные инструменты влияния на общественное мнение. Процесс реализации этих инструментов отражен в их названии, поэтому более детальное рассмотрение, по нашему мнению, не имеет смысла. Метод «общего вагона» основывается на стремлении человека быть частью какой-либо социальной общности. При использовании этого метода транслируется посыл, который якобы является присущим для большой социальной группы. Метод утечки секретной информации примечателен тем, что СМИ, использующие данный инструмент, не ответственны за продуцируемый контент. Метод «спирали молчания» заключается в том, чтобы заставить верить общество в то, что идея, выгодная манипуляторам, поддерживается большей частью общества. Мнимое меньшинство по ряду причин не в состоянии стать оппозицией мнимому большинству в медийной сфере.
В результате «спираль» закручивается сильнее, а манипуляторы достигают цели. Метод универсальности реализуется, в первую очередь, через апелляцию к авторитету и эксперту. Метод объективного подхода конструируется на основе фактологического ряда, который произвольно интерпретируется СМИ, а затем в реальность на основе анализа «запускается» тенденция или прогноз, который формирует общественное мнение. Метод семантического манипулирования - освещение СМИ тех или иных явлений политики словами, фразами, которые имеют негативные или позитивные коннотации в рамках данного общества. Каждый из данных методов манипуляции будет являться параметром для анализа контента отобранных нами сообществ в социальных сетях.

Кроме того, в нашем исследовании особое внимание уделяется анализу оппозиционных и провластных информационных поток с точки зрения их методов воздействия на внешнеполитические установки белорусов. Поэтому важно проанализировать коммуникативный менеджмент политических акторов страны с позиции их технологий продуцирования политического контента в Интернет-пространстве РБ. Например, подтверждает нашу позицию Е.А. Соловьева (Соловьева, 2011), которая рассматривает Интернет-среду в качестве пространства активного противоборства политических акторов страны. Ввиду этого целесообразно рассмотреть дискурс вокруг внешнеполитических установок белорусских пользователей, который, с точки зрения Е.А. Чурашовой (Чурашова, 2013), дифференцируется на дискурс защиты и дискурс обвинения. Отметим, что, несмотря на то, что данная работа анализирует протест 2011 года в РФ, данная типологизация медийного контента актуальна и для нашего исследования. Таким образом, классификация Е.А. Чурашовой трансформируется в следующие параметры нашей работы: дискурс защиты про- 
российской или прозападной позиции и дискурс обвинения (нападения) пророссийской или прозападной позиции, а также пятый показатель, который раскрывает иную сторону внешнеполитической ориентации граждан РБ (отражающую некий самобытный посыл).

Таким образом, нами проанализирован ряд концепций и теорий, с помощью которых были выведены параметры анализа информационных потоков в сетевой среде. Помимо параметров, указанных выше, следует отметить еще несколько показателей, которые необходимы для более детального изучения единиц анализа в исследовании. В первую очередь, особый интерес для нас представляет язык, на котором ведется коммуникация. Как отмечалось выше, наше исследование носит билингвальный характер, поэтому среди параметров в матрице будет отдельным показателем «язык» со следующими переменными: 1 - русский язык; 2 белорусский язык. Второй, не менее важный параметр, это политическая ориентация актора, продуцирующего внешнеполитический контент в сетевом пространстве. В матрицу включен показатель «политическая ориентация», критериями которого являются: «власть или провластные силы» - 1 ; «оппозиция» - 2; «обыватели, формально не относящиеся к политической сфере» - 3 .

Таблица 1. Макет матрицы исследования Table 1. Layout of the research matrix

\begin{tabular}{|c|c|}
\hline $\begin{array}{l}\text { Показатель (параметр) / } \\
\text { Indicator (parameter) }\end{array}$ & Переменная (критерий) / Variable (criterion) \\
\hline Номер единицы анализа & $1, \ldots$ \\
\hline Язык единицы анализа & $\begin{array}{l}\text { 1-русский язык; } \\
\text { 2-белорусский язык }\end{array}$ \\
\hline $\begin{array}{l}\text { Политическая ориентация авторов } \\
\text { контента }\end{array}$ & $\begin{array}{l}\text { 1-провластная; } \\
\text { 2-оппозиционная; } \\
\text { 3-нейтральная }\end{array}$ \\
\hline $\begin{array}{l}\text { Манипулятивные } \\
\text { единицы анализа }\end{array}$ & $\begin{array}{l}\text { 1-метод повторения; } \\
\text { 2-метод наклеивания ярлыков; } \\
\text { 3-метод “общего вагона"; } \\
\text { 4-метод утечки секретной информации; } \\
\text { 5-метод “спирали молчания”; } \\
\text { 6-метод универсальности; } \\
\text { 7-метод объективного подхода; } \\
\text { 8-метод семантического манипулирования; } \\
\text { 9-отсутствие манипуляций, представленных в списке }\end{array}$ \\
\hline $\begin{array}{l}\text { Внешнеполитическая направлен- } \\
\text { ность и модальность единицы ана- } \\
\text { лиза }\end{array}$ & $\begin{array}{l}\text { 1-“‘ащита” пророссийской позиции; } \\
\text { 2-“нападение” на пророссийскую позицию; } \\
\text { 3-““ащита” прозападной позиции; } \\
\text { 4-“нападение” на прозападную позицию; } \\
\text { 5-внешнеполитическая сторона не отражает дихото-- } \\
\text { мичность (Россия/Запад), а выражает некую позицию } \\
\text { к иным субъектам международного права }\end{array}$ \\
\hline $\begin{array}{l}\text { Ссылка на единицу анализа в со- } \\
\text { циальной сети }\end{array}$ & \\
\hline
\end{tabular}


После составления матрицы для реализации данного исследования целесообразно сформировать пул сообществ для формирования необходимой для анализа выгрузки. С нашей точки зрения, для начала необходимо проанализировать сообщества, связанные с политическими акторами РБ. Например, политические партии являются ведущими политическими акторами, которые во многом определяют вектор внутренней и внешней политики. Особое место они занимают и в процессах формирования внешнеполитических установок. В связи с этим логично предположить, что политические партии играют важную роль в конструировании политического ландшафта РБ, а также являются создателями внешнеполитической повестки дня в медийном пространстве (Федорова, 2017). Согласно данным Центральной комиссии РБ по выборам и проведению республиканских референдумов, на сегодняшний день в РБ насчитывается 15 политических партий ${ }^{1}$. Однако политическая ситуация, складывающаяся вокруг них в стране, не позволяет нам в полной мере опираться на них в качестве ведущих политических акторов. Во-первых, по мнению некоторых экспертов, политические партии РБ утратили ряд своих функций (Котляров, 2010), в том числе и агитационную, частью которой является формирование образов субъектов международных отношений. Во-вторых, исходя из рейтингов политических партий, они не являются реально теми политическими силами, которые определяют внутриполитическую и внешнеполитическую ситуацию в республике. Так, например, по данным Института социологии НАН Беларуси уровень поддержки белорусских партий варьируется в районе статистической погрешности и составляет от 2,6 до $0,7 \%{ }^{2}$. Однако с нашей точки зрения, целесообразно проанализировать представленность этих политических акторов в медийном пространстве по причине отсутствия иных явных институциональных сил на внутриполитической арене РБ.

Для начала следует разделить их на провластные и оппозиционные по отношению к современному политическому курсу, который проводится президентом страны А.Г. Лукашенко. Объясняется данные критерий персоноцентричностью политической культуры страны. Нужно это разделение для более полного анализа и дальнейшей классификации технологий формирования внешнеполитических установок белорусских пользователей. Кроме того, пророссийский вектор политики условно ассоциируется с политикой провластных акторов в республике, а прозападный - с оппозиционным блоком акторов. За основу разделения партий по спектру лояльности к президенту страны возьмем работу А. Федута, О Богуцкого и В. Мартиновича (Федута, Богуцкий, Мартинович, 2003).

\footnotetext{
${ }^{1}$ Список политических партий // Центральная комиссия Республики Беларусь по выборам и проведению республиканских референдумов [Электронный pecypc] URL: http://rec.gov.by/ru/spisokpoliticheskih-partiy (дата обращения: 09.09.2019)
} 
Таблица 2. Политическая ориентация партий Table 2. Political orientation of parties

\begin{tabular}{|c|c|}
\hline $\begin{array}{c}\text { Провластные партии / Pro-government } \\
\text { parties }\end{array}$ & $\begin{array}{c}\text { Оппозиционные партии / Opposition } \\
\text { parties }\end{array}$ \\
\hline Коммунистическая партия Беларуси & $\begin{array}{l}\text { Белорусская партия левых “Справедли- } \\
\text { вый мир” }\end{array}$ \\
\hline $\begin{array}{l}\text { Республиканская партия труда и спра- } \\
\text { ведливости }\end{array}$ & Белорусская партия “Зелёные” \\
\hline Республиканская партия & Объединённая гражданская партия \\
\hline Белорусская аграрная партия & Партия БНФ \\
\hline $\begin{array}{l}\text { Белорусская социально-спортивная пар- } \\
\text { тия }\end{array}$ & $\begin{array}{l}\text { Консервативно-Христианская Партия - } \\
\text { БНФ }\end{array}$ \\
\hline Белорусская патриотическая партия & $\begin{array}{l}\text { Белорусская социал-демократическая } \\
\text { партия (Грамада) }\end{array}$ \\
\hline \multirow[t]{2}{*}{$\begin{array}{l}\text { Социал-демократическая партия Народ- } \\
\text { ного Согласия }\end{array}$} & $\begin{array}{l}\text { Партия “Белорусская } \\
\text { демократическая Грамада” }\end{array}$ \\
\hline & Либерально-демократическая партия \\
\hline
\end{tabular}

Как отмечалось выше, помимо партий, иных явных и публичных политических сил, способных оказать влияние на общественное мнение, в том числе и в сфере внешнеполитических предпочтений, в РБ не выявлено.

Проанализировав рейтинги социальных сетей Республики Беларусь, мы смогли выявить явного лидера, медийный контент которого станет для нас информационной платформой исследования. Например, согласно данным Targeting.by., лидером среди социальных сетей в белорусском сегменте является ВКонтак$\mathrm{Te}^{3}$. По данным другого исследования, проведенного Online Market Intellegence, ВКонтакте - самая популярная социальная

\footnotetext{
${ }^{3}$ Социальные сети в Беларуси: статистика по белорусскому сегменту социальных сетей в 2017 году // Targeting.by. [Электронный pecypc] URL: https://targeting.by/sotsialnye-seti-belarusi-statistik/ (дата обращения: 09.09.2019)
}

сеть страны ${ }^{4}$. Вторит этим данным исследование Института социологии НАН Беларусь: ВКонтакте - самая широко используемая белорусами социальная сеть ${ }^{5}$. Таким образом, в данной работе будет фигурировать единственная социальная площадка, которая является безоговорочным лидером в белорусском Интернет-сегменте.

Кроме того, согласно работам С.Н. Федорченко (Федорченко, 2018) и его исследовательской группы, именно ВКонтакте является одной из самых политизированных сетей не только на территории

\footnotetext{
${ }^{4}$ ИССЛЕДОВАНИЕ ВЫЯВИЛО САМЫЕ ПОПУ ЛЯРНЫЕ СОЦСЕТИ И МЕССЕНДЖЕРЫ В БЕЛАРУСИ // Office Life [Электронный ресурс] URL: https://officelife.media/news/poll-what-socialnetworks-are-the-most-popular-in-belarus/ (дата обращения: 09.09.2019)

${ }^{5}$ Какие соцсети популярнее всего у белорусов? Институт социологии НАН Беларусь [Электронный pecypc] URL: http://socio.bas-net.by/kakie-sotssetipopulyarnee-vsego-u-belorusov/ (дата обращения: 15.09.2019)
} 
РБ, но и на всем постсоветском пространстве. Отметим также, что, по данным того же исследования, высоким уровнем политизированности отличаются и другие социальные сети, например, Facebook. Однако исходя из анализа численности аудитории социальных сетей в республике, можно уверенно сказать, что иные социальные сети, которые отличаются высокой долей политического контента в своем информационном потоке, не подходят в силу сравнительно невысокого уровня популярности среди Интернет-аудитории РБ.
Следовательно, ВКонтакте будет являться Интернет-платформой данного исследования. Контент этой социальной сети будет являться эмпирической базой единичных объектов анализа: каждый пост определенных нами групп и сообществ мы будем рассматривать в качестве единицы анализа. Характеризовать каждый из них мы будем по описанным выше параметрам.

Следуя логике нашего исследования, следует проанализировать представленность политических партий Республики Беларусь в социальной сети (ВКонтакте).

Таблица 3. Представленность политических партий в социальной сети Table 3. Representation of political parties in a social network

\begin{tabular}{|c|c|c|c|}
\hline $\begin{array}{c}\text { Название партии / } \\
\text { Party name }\end{array}$ & $\begin{array}{c}\text { Кол-во } \\
\text { групп в } \\
\text { соц.сети / } \\
\text { The number } \\
\text { of groups in } \\
\text { social net- } \\
\text { works }\end{array}$ & $\begin{array}{c}\text { Кол-во подписчи- } \\
\text { ков в самой мно- } \\
\text { гочисленной } \\
\text { группе / The } \\
\text { number of } \\
\text { subscribers in the } \\
\text { largest group }\end{array}$ & Режим доступа / URL \\
\hline $\begin{array}{l}\text { Коммунистическая } \\
\text { партия Беларуси }\end{array}$ & 6 & 7005 & https://vk.com/compartyby \\
\hline $\begin{array}{l}\text { Республиканская } \\
\text { партия труда и спра- } \\
\text { ведливости }\end{array}$ & 1 & 900 & https://vk.com/rptsnewsagensy \\
\hline $\begin{array}{l}\text { Республиканская } \\
\text { партия }\end{array}$ & - & - & - \\
\hline $\begin{array}{l}\text { Белорусская } \\
\text { ная партия }\end{array}$ & - & - & - \\
\hline $\begin{array}{l}\text { Белорусская соци- } \\
\text { ально-спортивная } \\
\text { партия }\end{array}$ & - & - & - \\
\hline $\begin{array}{l}\text { Белорусская патрио- } \\
\text { тическая партия }\end{array}$ & - & - & - \\
\hline $\begin{array}{l}\text { Социал-демократи- } \\
\text { ческая партия } \\
\text { Народного Согласия }\end{array}$ & - & - & - \\
\hline $\begin{array}{l}\text { Белорусская партия } \\
\text { левых “Справедли- } \\
\text { вый мир” }\end{array}$ & 2 & 7882 & https://vk.com/spravedlivy_mir \\
\hline
\end{tabular}




\begin{tabular}{|c|c|c|c|}
\hline (A & \multicolumn{3}{|c|}{$\begin{array}{r}\text { Научный результат. Социальные и гуманитарные исследования. 2020. T. 6, № 1. С. 74-89 } \\
\text { Research Result. Social Studies and Humanities. 2020. Vol. 6, № 1. P. 74-89 }\end{array}$} \\
\hline $\begin{array}{l}\text { Белорусская партия } \\
\text { "Зелёные" }\end{array}$ & - & - & - \\
\hline $\begin{array}{l}\text { Объединённая граж- } \\
\text { данская партия }\end{array}$ & - & - & - \\
\hline Партия БНФ & 6 & 1665 & https://vk.com/club4932319 \\
\hline $\begin{array}{l}\text { Консервативно- } \\
\text { Христианская Пар- } \\
\text { тия - БНФ }\end{array}$ & 1 & 517 & https://vk.com/narodnajapartyja \\
\hline $\begin{array}{l}\text { Белорусская социал- } \\
\text { демократическая } \\
\text { партия (Грамада) }\end{array}$ & - & - & - \\
\hline $\begin{array}{l}\text { Партия "Белорусская } \\
\text { социал- } \\
\text { демократическая } \\
\text { Грамада" }\end{array}$ & 2 & 218 & https://vk.com/bsdp.hramada \\
\hline $\begin{array}{l}\text { Либерально- } \\
\text { демократическая } \\
\text { партия }\end{array}$ & 3 & 2784 & https://vk.com/ldprb \\
\hline
\end{tabular}

Таким образом, мы видим явный перекос представленности в медийной сфере политических партий в сторону оппозиционного блока. Скорее всего, такое положение дел связано с тем, что, во-первых, провластный блок опирается в своем коммуникационном менеджменте не на Интернет-среду, а на телевидение, в то время как оппозиция практически не имеет доступа к телевизионному информационному потоку, а во-вторых, правительственный блок представляет из себя совокупность одного крупного политического игрока (Коммунистическая партия) и ряда «карликовых» партий, которые лишены собственных полноценных политических амбиций, в отличие от оппозиции, которая преследует собственные интересы и реализует собственную коммуникационную стратегию согласно своим целями и задачам. Следовательно, в рамках нашего анализа мы будем рассматривать контент четырех политических партий: Коммунистическая партия Беларуси, Белорусская партия левых “Справедливый мир”,
Партия БНФ, Либерально-демократическая партия. Отметим, что сетевые группы, число подписчиков которых не достигает 1000 , не взяты нами для анализа их контента, так как их потенциал влияния на Интернет-аудиторию очень мал.

Следует отметить, что в эпоху Интернет-коммуникаций политическая агитация отходит от формального (сугубо институционального) подхода. Поэтому, на наш взгляд, целесообразно анализировать группы, которые напрямую не связаны с официальными политическими институтами страны. Согласно медийным рейтингам, нам следует обратить внимание на два сообщества, контент которых состоит в том числе и из политического дискурса 6 . Первая из них, «Чай з малинавым варэннем»- ообество, популярное в белорусском сегменте Интернета своим ироничным и саркастическим контентом,

\footnotetext{
6 Топ-10 белорусских групп ВКонтакте, на которые стоит подписаться // Наша Нива [Электронный реcypc] URL: https://nn.by/?c=ar\&i=191072\&lang=ru (дата обращения: 09.09.2019)
} 
который отражает политическую реальность страны. Второе сообщество - «Мая краіна Беларусь», интересное для нас тем, что языком, на котором ведется группа, является белорусский. Кроме того, политические темы занимают определенную долю в продуцируемом информационном контенте группы. Помимо упомянутых групп также интерес для нашего исследования представляют менее популярные, но более политизированные сообщества ВКонтакте: «STOP LUKA», «Калі ласка Беларусь», «За сильную и процветающую Беларусь» и «Чеснок».

Таким образом, нами отобрано для когнитивного картирования информационного потока 10 социальных сообществ сети ВКонтакте: КХП-БНФ - Народная партыя (режим доступа: https://vk.com/narodnajapartyja); Либерально-демократическая партия (режим доступа: https://vk.com/ldprb); Белорусская партия левых “Справедливый мир” (режим доступа: https://vk.com/spravedlivy_mir); Коммунистическая партия Беларуси (режим доступа: https://vk.com/compartyby); "Чай $з$ малинавым варэннем" (режим доступа: https://vk.com/belteanews); "Мая краіна Беларусь” (режим доступа: https://vk.com/majakrainabelarus); "STOP LUKA" (режим доступа: https://vk.com/stopluka), "Калі ласка - Беларусь” (режим доступа: https://vk.com/kalilaskabelarus), “За сильную и процветающую Беларусь” (режим доступа: https://vk.com/club24982282) и "Чеснок" (режим доступа: https://vk.com/4esnok_by). Подчеркнем, что глубина анализа - период с 01.01.2019 до 20.05.2019.

После анализа матрицы исследования, состоящей из 452 единиц анализа, (режим доступа: https://docs.google.com/spreadsheets/d/11jTn x1zdjZkUQ2GtkFJUT3fqvgB5EvOGx12pjcC $\mathrm{X} 1 \mathrm{DQ} / \mathrm{edit}$ ?usp=sharing) в программе SPSS Statistics нами были получены следующие результаты:

\section{Осевой анализ:}

\section{Язык}

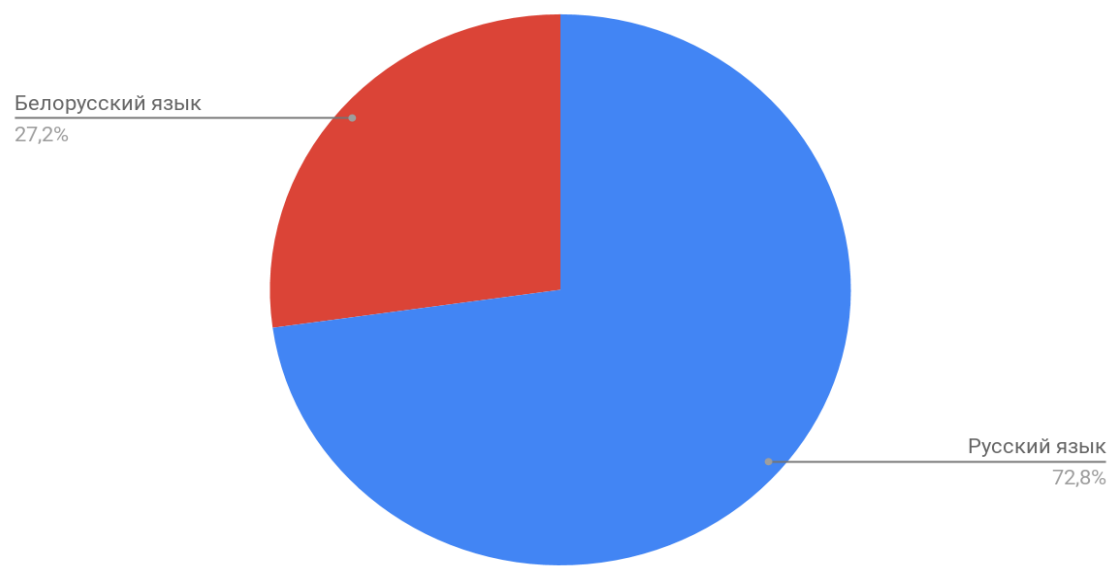

Рис. 1. Язык внешнеполитического дискурса

Fig. 1. Language of foreign policy discourse 
Как видно из данных таблицы, русский язык является ведущим языком об

щения белорусов в Интернет-среде.

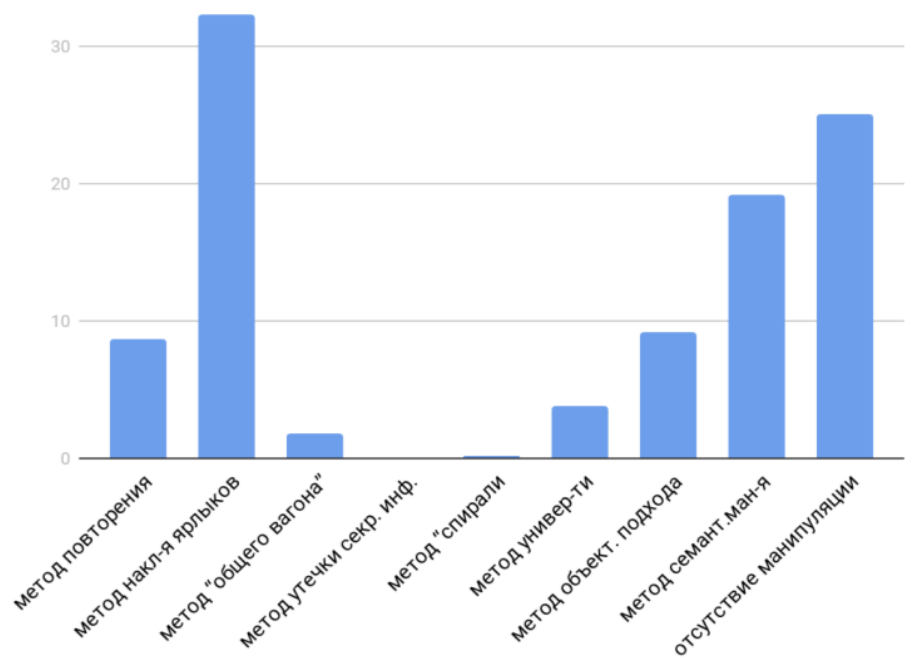

Рис. 2. Технологии манипуляциий внешнеполитического дискурса

Fig. 2. Technology manipulation of foreign policy discourse

Метод повторения, наклеивания ярлыков и семантического манипулирования оказались самыми популярными у политических акторов РБ для формирования внешнеполитических установок. Объясняется это простотой и эффективностью данных методов манипулирования общественным сознанием.

Метод повторения проявлялся в основном в виде заголовка текста или фразы манипулятивного характера в тексте («Бабич перепутал страну с регионом») и картинки в посте ниже текста, на которой была такая же запись.

Метод наклеивания ярлыков проявлялся главным образом в адрес восточных соседей (слова «убийцы», «оккупанты» встречались часто в правоориентированных сообществах).
Метод семантического манипулирования связан со словами, которые вызывали бы в обществе неприятные коннотации. Зачастую в рамках современного дискурса используются «заменители» из прошлых эпох для именования политических акторов внутри РБ и за ее пределами. Например, вместе со словами «россияне» или «русские» рядом находилось слово «НКВДшник».

Что касается большой доли «безманипулятивных» единиц анализа, то стоит отметить в данной ситуации узость выбранных нами методов манипуляции. В дальнейшем считаем необходимым расширить список и добавить в него целый ряд механизмов манипулятивного влияния. 


\section{Внешнеполитическая направленность}

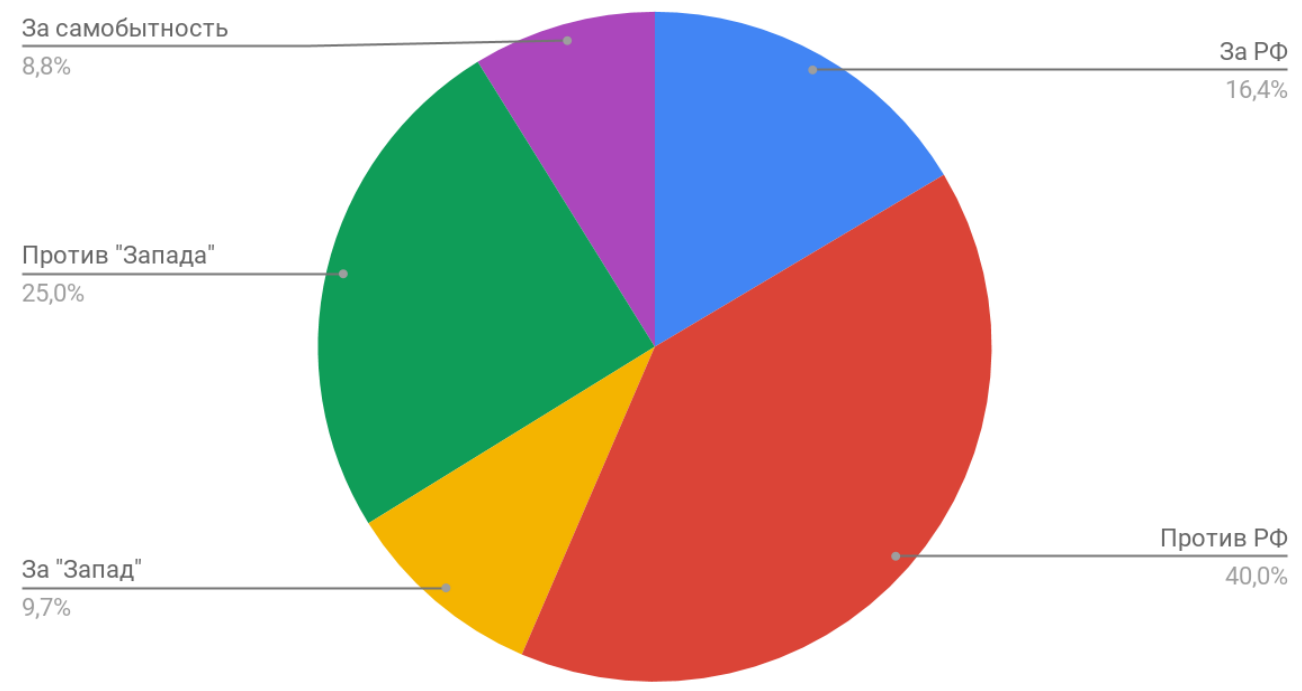

Puc. 3. Внешнеполитическая ориентация дискурса

Fig. 3. Foreign policy orientation of the discourse

Как видно из рисунка, наше предположение относительно дихотомичности внешнеполитического дискурса в РБ оправдалось. Стоит отметить, что контент с российской тематикой преобладает над всеми остальными. Скорее всего, подобная ситуация связана с уплотнением информационного потока, связанного с проблематикой ускорения интеграции в рамках Coюзного государства.

Кросс-табуляционный анализ (сопряжение нескольких параметров):

\section{Язык и позиция}

Таблица 4. Сопряжения языка и политической направленности актора Table 4. The conjugation of the language and political orientation of the actor

\begin{tabular}{|l|c|c|c|}
\hline & $\begin{array}{c}\text { Провластная } \\
\text { Позиция / Рro- } \\
\text { government } \\
\text { position }\end{array}$ & $\begin{array}{c}\text { Оппозиционная } \\
\text { позиция / } \\
\text { Орposition posi- } \\
\text { tion }\end{array}$ & $\begin{array}{c}\text { Нейтральная } \\
\text { Позиция / Neutral } \\
\text { роsition }\end{array}$ \\
\hline $\begin{array}{l}\text { Русский } \\
\text { язык / Russian } \\
\text { language }\end{array}$ & $11 \%$ & $16,8 \%$ & $44,9 \%$ \\
\hline $\begin{array}{l}\text { Белорусский } \\
\text { язык / Belarusian } \\
\text { language }\end{array}$ & 0 & $0,8 \%$ & $26,5 \%$ \\
\hline
\end{tabular}

Как видно из таблицы, языком официального политического дискурса является русский. Однако ситуация с белорусским языком и его использование для не- формального политического общения может свидетельствовать о его «перетекании» в среднесрочной перспективе в ведущий политический язык сетевой среды. 


\section{Позиция и манипуляция}

Провластные и оппозиционные сообщества используют одинаковые манипулятивные механизмы и примерно в равном количестве. Самыми манипулятивными являются группы, декларирующие нейтральную политическую позицию. В связи с этим следует отметить, что основной внешнеполитический дискурс идет именно в нейтральных сообществах.

\section{Внешнеполитическая направленность и язык}

Таблииа 5. Сопряжение языка и внешнеполитическая позиция Table 5. Language conjugation and foreign policy position

\begin{tabular}{|c|c|c|c|c|c|}
\hline & $\begin{array}{c}\text { "Защита" } \\
\text { PФ / "Protecti } \\
\text { on" of the RF }\end{array}$ & $\begin{array}{c}\text { "Против" } \\
\text { РФ / "Again } \\
\text { st" the RF }\end{array}$ & $\begin{array}{c}\text { "Защита" } \\
\text { Запада" / P } \\
\text { rotection" } \\
\text { of the West }\end{array}$ & $\begin{array}{c}\text { "Против" } \\
\text { Запада“ / A } \\
\text { gainst" the } \\
\text { West }\end{array}$ & $\begin{array}{c}\text { Самобыт- } \\
\text { ность / } \\
\text { Identity }\end{array}$ \\
\hline $\begin{array}{l}\text { Русский } \\
\text { язык / } \\
\text { Russian } \\
\text { language }\end{array}$ & $16 \%$ & $19 \%$ & $5,7 \%$ & $24,7 \%$ & $7,3 \%$ \\
\hline $\begin{array}{l}\text { Белорус- } \\
\text { ский } \\
\text { язык / Bel } \\
\text { arusian } \\
\text { language }\end{array}$ & $0,4 \%$ & $21 \%$ & $3,9 \%$ & $0,2 \%$ & $1,8 \%$ \\
\hline
\end{tabular}

Белорусский язык используется главным образом для «нападения» на пророссийскую сторону и «защиты» прозападной позиции, что логично было предположить. Однако русский язык в большей степени используется для «нападения» на пророс- сийскую сторону, чем для ее защиты. Возможно, это связано с тем, что русский язык, как отмечалось выше, является «официальным» языком политического дискурса в медийной сфере.

\section{Внешнеполитическая направленность и позиция}

Таблица 6. Сопряжение внешнеполитической ориентации и политической позиции Table 6. The combination of foreign policy orientation and political position

\begin{tabular}{|c|c|c|c|c|c|}
\hline & $\begin{array}{c}\text { "Защита" } \\
\text { PФ / "Protec } \\
\text { tion" of the } \\
\text { RF }\end{array}$ & $\begin{array}{c}\text { "Против" } \\
\text { РФ / "Against } \\
\text { " the RF }\end{array}$ & $\begin{array}{c}\text { "Защита" } \\
\text { Запада" / Pro } \\
\text { tection" of the } \\
\text { West }\end{array}$ & $\begin{array}{c}\text { “Против" } \\
\text { Запада“ / Aga } \\
\text { inst" the West }\end{array}$ & $\begin{array}{c}\text { Самобыт- } \\
\text { ность / } \\
\text { Identity }\end{array}$ \\
\hline $\begin{array}{l}\text { Про- } \\
\text { властная } \\
\text { позиция / } \\
\text { Progov- } \\
\text { ernment } \\
\text { position }\end{array}$ & $6,4 \%$ & $0,5 \%$ & $0,2 \%$ & $2,4 \%$ & $1,5 \%$ \\
\hline
\end{tabular}




\begin{tabular}{|l|c|c|c|c|c|}
$\begin{array}{l}\text { Оппози- } \\
\text { ционная } \\
\text { позиция / } \\
\text { Орроsition } \\
\text { роsition }\end{array}$ & $0,5 \%$ & $11,5 \%$ & $2,8 \%$ & 0 & $2,8 \%$ \\
\hline $\begin{array}{l}\text { Нейтраль } \\
\text { ная пози- } \\
\text { ция / Neutr } \\
\begin{array}{l}\text { al } \\
\text { роsition }\end{array}\end{array}$ & $9,5 \%$ & $28 \%$ & $6,8 \%$ & $22,5 \%$ & $4,6 \%$ \\
\hline
\end{tabular}

С нашей точки зрения, данные этой таблицы предсказуемы: провластные сетевые группы пророссийски ориентированы, а оппозиционные и нейтральные (среди нейтральных сообществ уровень употребления белорусского языка самый высокий) группы - прозападны. Однако общая тенденция прослеживается явно: в белорусском Интернет-сегменте есть запрос на критику как пророссийского курса, так и прозападного. Это говорит о том, что белорусское общество стремится в равной степени обособиться от России и Запада, что, на наш взгляд, связано с подъемом «правых» идей в РБ.

Таким образом, на основе автоматизированного анализа данных нами было сделано несколько основных выводов:

- языком политического дискурса в сетевом пространстве служит русский язык;

- наиболее высоким уровнем манипулятивности характеризуются нейтральные сообщества;

- белорусский язык преобладает в нейтральных сообществах и в единицах анализа (политических высказываниях) с антироссийским показателем внешнеполитической ориентации;

- основной внешнеполитический дискурс связан с РФ;

- внешнеполитическая позиция провластных групп - пророссийская, оппозиционных - прозападная, у нейтральных - негативная по отношению к Западу и к России;

- основными методами манипуляций являются: метод повторения, метод наклеивания ярлыков и метод семантического манипулирования.

В перспективе данное исследование может быть основой для более масштабных работ с большим количеством параметров и более широкой выборочной совокупностью единиц анализа. Также возможна модернизация отбора сообществ в связи с более детальным изучением белорусского политического ландшафта и нахождением в нем новых политических акторов, выходящих за рамки институционального подхода. Более того, анализ релевантных информационных потоков целесообразно расширить за счет SMA (наиболее оптимальные инструменты: IQBuzz или YouScan).

\section{Литература}

Грин, С. «Твиттер» и протест в России: мемы, сети, мобилизация // Интернет-издание «Слон Ру» [Электронный ресурс] URL: http://slon.ru/russia/tvitter_i_protest_v_rossii_me my_seti_i_mobilizatsiya-791222.xhtml (дата обращения: 13.09.2019).

Ибрагимов, Л.Х. Технологии интернетманипуляции в сетевом пространстве политики // Контуры глобальных трансформаций: политика, экономика, право. 2015. № 2 (40) [Электронный pecypc] URL: https://cyberleninka.ru/article/n/tehnologiiinternet-manipulyatsii-v-setevom-prostranstvepolitiki (дата обращения: 11.09.2019).

Котляров, И.В. Политические партии Беларуси в начале XXI в.: социальнополитический анализ // Социологический альманах. 2010. № 1 [Электронный ресурс] URL: https://cyberleninka.ru/article/n/politicheskiepartii-belarusi-v-nachale-xxi-v-sotsialno- 
politicheskiy-analiz

(дата

обращения:

09.05.2019).

Рощин, С.К. Западная психология как инструмент идеологии и политики. М., 1980. $304 \mathrm{c}$.

Соловьева, Е.А. Информационное противоборство в сети Интернет: политологический анализ: дис. ... канд. полит. наук. 2011. [Электронный pecypc] URL: http://www.dissercat.com/content/informatsionno e-protivoborstvo-v-seti-internetpolitologicheskiianaliz (дата обращения: 09.09.2019).

Узнадзе, Д.Н. Экспериментальные основы психологии установки. Москва, 1949

Федорова, Е.Д. Теория установления повестки дня // Гуманитарные научные исследования. 2017. № 5 [Электронный ресурс]. URL: http://human.snauka.ru/2017/05/23985 (дата обращения: 09.09.2019).

Федорченко, С.Н. Финальный аккорд: III волна исследования политизации социальных сетей Интернета // Журнал политических исследований. 2018. Т. 2. № 3 [Электронный ресурс] https://naukaru.ru/ru/nauka/article/23664/view (дата обращения: 09.05.2019).

Федута, А., Богуцкий, О., Мартинович, В. Политические партии Беларуси - необходимая часть гражданского общества: Материалы семинара. Минск: Фонд имени Фридриха Эберта, 2003. 113 с.

Чурашова, Е.А. Дискурсивные стратегии политической коммуникации в кризисной ситуации: автореф. дис. ... канд. политич. наук. 2013. [Электронный ресурс] URL: kpfu.ru/portal/docs/F1290978712/avtoreferat.Chu rashova.docx. (дата обращения: 09.09.2019).

Шихирев, П.Н. Современная социальная психология. М.: ИП РАН; КСП+. Екатеринбург: Деловая книга, 2000. 448 с.

Castells, M. The Rise of the network society [Электронный pecypc] URL: https://pdfs.semanticscholar.org/3746/ef34fd58d0 47d973008a0a723f832a83797e.pdf (дата обращения: 23.09.19).

Huntington, S.P. The clash of civilizations [Электронный pecypc] URL: https://www.litres.ru/semuelhantington/stolknovenie-civilizaciy/chitat-onlayn/ (дата обращения: 23.09.2019).

\section{References}

Castells, M. (2010), The Rise of the network society [Online] https://pdfs.semanticscholar.org/3746/ef34fd58d0 47d973008a0a723f832a83797e.pdf (Accessed: 23.09.19).

Churashova, E.A. (2013), "Discursive strategies for political communication in a crisis situation", Abstract of Ph.D. dissertation, political science [Online] URL: kpfu.ru/portal/docs/F1290978712/avtoreferat.Chu rashova.docx. (Accessed: 09.09.2019) (in Russ.).

Fedorchenko, S.N. (2018), "The final chord: the third wave of research on the politicization of Internet social networks", Zhurnal politicheskikh issledovanij [Journal of political research], 2 (3) [Online] URL: https://naukaru.ru/ru/nauka/article/23664/view (Accessed: 09.05.2019) (in Russ.).

Fedorova, E.D. (2017), "The theory of setting the agenda", Gumanitarnye nauchnye issledovaniya [Humanitarian scientific researches], (5) [Online] URL: http://human.snauka.ru/2017/05/23985 (Accessed: 09.09.2019) (in Russ.).

Feduta, A., Bogutskij, O., Martinovich, V. (2003), Politicheskie partii Belarusi-neobkhodimaya chast' grazhdanskogo obschestva: Materialy seminara [Political parties in Belarus are a necessary part of civil society: materials of the seminar], Fond imeni Fridrikha Ehberta, Minsk, Belarus (in Russ.).

Grin, S. (2012), "'Twitter' and protest in Russia: memes, networks, mobilization", "Slon $R u$ " [Online] URL: http://slon.ru/russia/tvitter_i_protest_v_rossii_me my_seti_i_mobilizatsiya-791222.xhtml (Accessed: 13.09.2019) (in Russ.).

Huntington, S.P. The clash of civilizations [Online] URL: https://www.stetson.edu/artsci/politicalscience/media/clash.pdf (Accessed: 23.09.2019)

Ibragimov, L.Kh. (2015), "Technologies of Internet manipulation in the network space of politics", Kontury global'nykh transformatsij: politika, ehkonomika, pravo [Contours of global transformations: politics, Economics, law], 2 (40) [Online] URL: https://cyberleninka.ru/article/n/tehnologiiinternet-manipulyatsii-v-setevom-prostranstvepolitiki (Accessed: 11.09.2019) (in Russ.).

Kotlyarov, I.V. (2010), "Political parties in Belarus at the beginning of the XXI century: socio-political analysis", Sotsiologicheskij al'manakh [A sociological almanac], 1 [Online] URL:

https://cyberleninka.ru/article/n/politicheskie- 
partii-belarusi-v-nachale-Xxi-V-sotsialno-

politicheskiy-analiz (Accessed: 09.05.2019) (in Russ.).

Roshchin, S.K. (1980), Zapadnaya psikhologiya kak instrument ideologii $i$ politiki [Western psychology as an instrument of ideology and politics], Moscow, Russia (in Russ.).

Shikhirev, P.N. (2000), Sovremennaya sotsial'naya psikhologiya [Modern social psychology], IP RAN, KSP+, Moscow, Delovaya kniga, Ekaterinburg, Russia (in Russ.).

Solov'eva, E.A. (2011), "Information confrontation on the Internet: political analysis", Ph.D. Thesis, political science [Online] URL: http://www.dissercat.com/content/informatsionno e-protivoborstvo-v-seti-internetpolitologicheskiianaliz (Accessed: 09.09.2019).

Uznadze, D.N. (1949), Ehksperimental'nye osnovy psikhologii ustanovki [Experimental foundations of installation psychology], Moscow, Russia (in Russ.).

Информация о конфликте интересов: авторы не имеют конфликта интересов для деклараций.

Conflict of Interests: the authors have no conflict of interests to declare.

\section{ОБ АВТОР АX:}

Домбровская Анна Юрьевна, доктор социологических наук, доцент, заместитель заведующего кафедрой по научной работе, Московский педагогический государственный университет, ул. Малая Пироговская, д. 1, стр. 1, Москва, 119991, Россия; au.dombrovskaya@mpgu.su

Никулин Егор Романович, студент 4-го курса Института истории и политики, Московский педагогический государственный университет, ул. Малая Пироговская, д. 1, стр. 1, Москва, 119991, Россия; egor.nikulin.98@bk.ru

\section{ABOUT THE AUTHORS:}

Anna Yu. Dombrovskaya, Doctor of Sociology, Associate Professor, Deputy Head of the Department of Scientific Work, Moscow State Pedagogical University, bld. 1, 1 Malaya Pirogovskaya St., Moscow, 119991, Russia; au.dombrovskaya@mpgu.su

Egor R. Nikulin, Student of the Institute of History and Politics, Moscow State Pedagogical University, bld. 1, 1 Malaya Pirogovskaya St., Moscow, 119991, Russia; egor.nikulin.98@bk.ru 